\title{
Dimensi yang Berhubungan dengan Penerapan Budaya Keselamatan Pasien di Rumah Sakit
}

\author{
Elsya Fitri Syofian \\ elsyafitrisyofian93@gmail.com
}

\begin{abstract}
ABSTRAK
Budaya keselamatan pasien merupakan langkah utama dalam meningkatkan keselamatan pasien. Membangun budaya keselamatan pasien merupakan kata kunci terwujudnya pelayanan yang bermutu dan aman. Terdapat beberapa aspek yang berhubungan dalam menerapkan budaya keselamatan pasien di rumah sakit. Dimensi tersebut antara lain kerja sama, komunikasi, kepemimpinan, pelaporan, dan respon tidak menghukum terhadap kesalahan. Dengan menerapkan budaya keselamatan pasien yang baik kan meningkatkan mutu pelayanan serta meningkatkan keselamatan pasien pula.
\end{abstract}

Kata kunci: Budaya Keselamatan Pasien, Dimensi

\section{Latar Belakang}

Rumah Sakit merupakan salah satu unit pelayanan kesehatan yang menyediakan pelayanan kesehatan bagi seluruh lapisan masyarakat dalam memenuhi setiap kebutuhan dan haknya dalam memperoleh pelayanan kesehatan yang bermutu dan berkualitas (Nursalam, 2015; Ilyas, 2004). Sebagai sarana pelayanan kesehatan yang bersifat kompleks, Rumah Sakit memiliki sumber daya dengan berbagai multidisiplin ilmu, sehingga besar kemungkinan untuk terjadi masalah atau Kejadian yang Tidak Diharapkan (KTD) dalam pemberian pelayanan kesehatan (Triwibono, 2013; Pohan, 2015).

Putra (2016), menyebutkan bahwa peningkatan mutu pelayanan kesehatan dalam ruang lingkup rumah sakit menjadi isu utama dalam pembangunan kesehatan 
baik dalam lingkup nasional maupun global. Cahyono, (2008) dimensi mutu salah satunya diukur melalui keselamatan pasien. Keselamatan pasien dipengaruhi oleh bagaimana budaya individu dan sistem yang berjalan di dalam organisasi tersebut. Sehingga harus dilakukan pendekatan secara personal/individu maupun sistem manajemen di dalam institusi tersebut.

Peran perawat dalam keselamatan pasien tergambar dan banyak hal yang terkait dengan kebutuhan keselamatan pasien. Salah satunya adalah budaya keselamatan (Hadi, 2017). Budaya keselamatan pasien merupakan langkah utama dalam meningkatkan keselamatan pasien. Pemimpin merupakan motor penggerak untuk melakukan aktifitas sesuai dengan yang diharapkan organisasi. Promosi budaya keselamatan pasien yang baik merupakan pelaksanaan dari intervensi yang mendasar dari kepemimpinan yang akan merubah perilaku anggota tim (Weaver et al., 2013).

Budaya keselamatan pasien adalah nilai- nilai, sikap, persepsi kompetensi dan pola perilaku dari individu yang menentukan komitmen dan gaya kemampuan manajemen rumah sakit dalam meminimalkanpajanan yang membahayakan atau mencelakakan karyawan, manajemen pasien, atau anggota masyarakat lainnya. Manfaat utama dalam budaya keselamatan pasien adalah organisasi menyadari apa yang salah dan pembelajaran terhadap kesalahan tersebut.

Terdapat beberapa aspek yang berhubungan dalam menerapkan budaya keselamatan pasien di rumah sakit. Dimensi tersebut antara lain kerja sama, komunikasi, kepemimpinan, pelaporan, dan respon tidak menghukum terhadap kesalahan. Dalam kajian ini akan dibahas lebih lanjut mengenai aspek-aspek yang berhubungan dengan penerapan budaya keselamatan pasien di rumah sakit.

\section{Metode}

Metode yang digunakan adalah metode literature review. Metode yang berlandaskan teori yang mengumpulkan data yang telah disimpulkan dari berbagai sumber yaitu dari buku, koran, majalah, jurnal print maupun jurnal online, serta $e$ book dengan tahun paling tua 2012 yang memuat segala informasi mengenai berbagai dimensi yang berhubungan dengan penerapan budaya untuk meningkatkan keselamatan pasien di rumah sakit. Dengan berdasarkan sumber-sumber tersebut Saya dapat memahami bagaimana aspek dimensi 
tersebut dapat berpengaruh dalam lingkup kerja perawat dalam menerapkan budaya keselamatan pasien di rumah sakit.

\section{Hasil}

Penerapan budaya keselamatan pasien di rumah sakit penting dilakukan agar dapat mewujudkan pelayanan yang bermutu dan aman. Fokus pada budaya keselamatan pasien akan lebih berhasil Apabila dibandingkan hanya fokus pada program keselamatan saja (Fleming, 2006; Reason 2000). Budaya keselamatan pasien secara garis besar dipengaruhi oleh 4 dimensi yaitu terbuka (open), adil (just) dan informatif dalam melaporkan kejadian yang terjadi (reporting) dan belajar dari kesalahan yang ada (learning).

Bersikap terbuka dan adil berarti berbagai informasi secara terbuka dan bebas dan berlaku adil bagi perawat ketika sebuah kejadian terjadi informasi yang akurat membantu dalam pencegahan kejadian dari keselamatan pasien. Sistem pelaporan digunakan untuk memberikan informasi kepada pihak managerial mengenai kejadian yang terjadi dan sebagai pembelajaran agar tidak terjadi kejadian yang sama untuk kedepannya. Budaya keselamatan pasien juga dapat mengurangi pengeluaran finansial yang diakibatkan oleh kejadian keselamatan pasien. Dalam menilai budaya keselamatan pasien di rumah sakit terdapat beberapa aspek atau dimensi yang perlu diperhatikan yaitu kerjasama antar tenaga kesehatan, komunikasi yang terbuka, kepemimpinan, pelaporan insiden, dan respon tidak menghukum terhadap kesalahan.

Kerjasama memiliki pengaruh terhadap keberhasilan peningkatan keselamatan pasien di rumah sakit. Kerjasama antar tim yang baik akan memberikan keefektifan saat memberikan pelayanan keperawatan dengan begitu akan mendukung penerapan budaya keselamatan pasien menjadi lebih baik. Disamping itu komunikasi juga dapat mempengaruhi keberhasilan melakukan penerapan budaya keselamatan pasien di rumah sakit. Segala informasi tentang keselamatan pasien harus jelas agar tidak mengakibatkan kerugian pada pasien jika komunikasi dilakukan dengan tidak jelas.

Pelaporan insiden berhubungan dengan keberhasilan penerapan budaya keselamatan pasien di rumah sakit. Perawat harus melaporkan seluruh kejadian mengenai keselamatan pasien dengan akurat dan jelas, hal tersebut dilakukan agar dapat mengidentifikasi akar dari masalah dan untung mencegah terjadinya kesalahan yang 
sama. Pelaporan insiden sebaiknya difokuskan dengan menindaklanjuti untuk memperbaiki kesalahan, bukan untuk menghukum pelaku yang berbuat kesalahan.

Peran pemimpin yaitu memiliki kemampuan untuk mempengaruhi orang untuk mencapai tujuan organisasi. Pemimpin harus menunjukkan komitmen terhadap keselamatan pasien dengan melatih dan memantai para tenaga kesehatan khususnya perawat untuk menerapkan budaya keselamatan pasien di rumah sakit. Dengan begitu akan terciptanya lingkungan yang aman dan nyaman serta dapat meningkatkan mutu pelayanan.

\section{Pembahasan}
Budaya keselamatan pasien yang baik akan membuat implementasi keselamatan pasien menjadi baik. Menurut Cahyono (2008), budaya keselamatan pasien merupakan fondasi keselamatan pasien. Membangun budaya keselamatan pasien merupakan kata kunci terwujudnya pelayanan yang bermutu dan aman. Dengan menerapkan budaya keselamatan pasien yang baik kan meningkatkan mutu pelayanan serta meningkatkan keselamatan pasien pula.

Budaya keselamatan yang ditandai dengan adanya alur informasi yang baik dan adanya proses komunikasi yang berkaitan dengan pembelajaran pada saat KTD, memiliki pemimpin yang komit dan eksekutif yang bertanggung jawab serta pendekatan untuk tidak menyalahkan dan tidak memberikan hukuman pada insiden yang dilaporkan merupakan budaya penting yang harus dibangun pada sebuah rumah sakit.

\section{Kerjasama}

Dalam penerapan budaya keselamatan pasien, kerjasama tim yang baik antar perawat pelaksana akan mendukung penerapan budaya keselamatan pasien menjadi lebih baik. Dalam melaksanakan asuhan keperawatan kepada pasien perawat akan selalu membutuhkan bantuan dari perawat maupun tenaga kesehatan yang lainnya. Bentuk kerjasama tidak hanya berupa saling membantu pekerjaan ketika perawat dihadapkan pada tugas yang sangat banyak dan membutuhkan penyelesaian yang sesegera mungkin, namun juga bisa berupa pembagian tugas berdasarkan kelompok kecil atau tim. 
Kerjasama tim yang efektif dapat diwujudkan melalui kesadaran dari masing-masing individu tentang pentingnya kerjasama dalam mencapai suatu tujuan, komunikasi yang terbuka, saling menghargai, mendukung dan mengingatkan antar anggota tim, tolongmenolong dan saling menggantikan kala rekan tim berhalangan atau merasa kelelahan secara fisik dan mental sehingga terbentuklah kerjasama tim yang baik dan efektif dalam menerapkan budaya keselamatan pasien.

Keterlibatan banyak profesi selain tenaga perawat dalam melakukan asuhan keperawatan dapat menimbulkan atau berisiko terjadi cidera jika dilakukan tidak dengan komunikasi dan koordinasi yang tepat, hal itu dapat dihindari jika perawat selalu menjaga hubungan baik dengan sesama perawat dan petugas kesehatan lainnya, dan menjaga keharmonisan di lingkungan kerja atau suasana hati untuk mencapai pelayanan kesehatan.

\section{Komunikasi}

Komunikasi dalam praktek keperawatan merupakan elemen penting bagi perawat dalam melaksanakan asuhan keperawatan untuk mendapatkan hasil yang optimal. Perawat memiliki peran yang paling dominan dalam mencegah terjadinya kesalahan dalam pengobatan, termasuk pelaporan insiden, mendidik diri sendiri dan perawat lain tentang penting komunikasi, memberikan rekomendasi untuk perubahan prosedur dan kebijakan serta keterlibatan dalam melakukan identifikasi permasalahan.

Pentingnya menjalin komunikasi dengan baik agar informasi yang disampaikan tidak terputus dan mengakibatkan kerugian pada pasien. Informasi tentang keselamatan pasien perlu diketahui oleh semua perawat yang memberikan asuhan keperwatan hal tersebut berfungsi untuk mencegah perawat melakukan tindakan yang dapat menyebabkan cidera pada pasien.

\section{Kepemimpinan}

Menurut (Nivalinda et al., 2013) Budaya keselamatan yang kuat membutuhkan kepemimpinan yang mampu menetapkan dan mengkomunikasikan visi keselamatan dengan jelas, menghargai dan memberdayakan staf untuk mencapai visi keselamatan pasien. 
Pimpinan mendorong dan menjamin implementasi program keselamatan pasien secara terintegrasi dalam organisasi melalui penerapan "Tujuh Langkah Menuju Keselamatan Pasien Rumah Sakit”

Pemimpin harus membangun komitmen dan fokus yang kuat dan jelas guna mendukung staff untuk menjalankan program keselamatan pasien secara berkesinambungan. Pimpinan mendorong dan menumbuhkan komunikasi dan koordinasi antar unit dan individu berkaitan dengan pengambilan keputusan tentang keselamatan pasien.

\section{Pelaporan}

Pelaporan insiden menjadi hal penting dalam perbaikan mutu pelayanan, sebab dapat digunakan sebagai koreksi bagi organisasi untuk memperbaiki sistem pelayanan yang ada di Rumah Sakit. Perawat diharuskan melaporkan kejadian kesalahan yang tidak disengaja dan kondisi yang mengakibatkan atau berpotensi mengakibatkan cedera yang dapat dicegah pada pasien.
Melaporkan sebuah kejadian atau insiden keselamatan pasien masih jarang dilakukan atau pun bahkan jika ada pelaporan tentang insiden atau kejadian keselamatan pasien belum ada pelaporan secara resmi. Hal ini disebabkan para perawat takut untuk melaporkan insiden yang terjadi pada pasien karena kesalahan yang dilakukannya.

Pelaporan insiden keselamatan pasien sangat dibutuhkan oleh semua pihak guna perbaikan pelayanan dalam hal ini khususnya asuhan keperawatan. Informasi dari pelaporan insiden keselamatan pasien yang akurat dan jelas dapat membantu identifikasi akar permasalahan bagaimana insiden tersebut bisa terjadi serta identifikasi faktor risiko sehingga insiden yang sama dapat dicegah. Informasi yang benar dan jelas yang diperoleh dari sistem pelaporan, asesmen risiko, kajian insiden, dan audit serta analisis, digunakan untuk menentukan solusi.

\section{Respon tidak menghukum terhadap kesalahan}

Sistem keselamatan pasien harus dibangun dalam lingkungan budaya yang tidak menyalahkan, namun lebih kepada mencari akar masalah atas suatu 
kesalahan untuk dapat selanjutnya melakukan koreksi sehingga tidak terjadi kesalahan yang sama.

Pelaporan terhadap insiden keselamatan pasien tidak semata-mata hanya berupa pelaporan insiden keselamatan, namun pelaporan tersebut hendaknya ditindaklanjuti guna memperbaiki kesalahan dan mencari akar permasalahan, tidak untuk menghukum perawat yang melakukan kesalahan atau berpengaruh terhadap penilainan kinerjanya. Ketika kesalahan dilaporkan, maka cukup melaporkan masalah sendiri dilaporkan menemukan jalan keluar tidak menunjukkan siapa pelaku harus dihukum.

Sebagaimana diatur dalam Peraturan Menteri Kesehatan Republik Indonesia nomer 755/Menkes/Per/IV/2011 tentang pelaksanaan komite medis di rumah sakit bahwa audit medis dilakukan dengan memprioritaskan semua staf untuk menghilangkan blaming (menyalahkan), naming (menyebut atau mencari siapa yang salah), dan shaming (mempermalukan atau mengakui kesalahan).

\section{Penutup}

Keselamatan pasien di rumah sakit melibatkan partisipasi dari semua petugas kesehatan, terutama perawat. Perawat sebagai profesi tenaga kesehatan dengan jumlah paling besar diantara tenaga kesehatan lainnya dan paling lama kontak dengan pasien, dianggap mempunyai peran penting dalam mengukur, memonitor serta memperbaiki kualitas asuhan serta keamanan pasien. Dimensi-dimensi yang berhubungan dengan penerapan budaya keselamatan pasien di rumah sakit antara lain kerjasama tim, komunikasi yang terbuka, kepemimpinan, pelaporan insiden, dan respon tidak menghukum terhadap kesalahan. Dengan meningkatkan penerapan budaya keselamatan pasien diharapkan perawat dapat memberikan perawatan yang komprehensif dan berpusat pada kebutuhan pasien sehingga keselamatan pasien dirumah sakit dapat tercapai. 


\section{Daftar Pustaka}

Anggraeni, D., \& Azzuhri, M. (2016). Pengaruh budaya keselamatan pasien terhadap sikap melaporkan insiden pada perawat di Instalasi Rawat Inap Rumah Sakit Tk. II dr. Soepraoen. Jurnal aplikasi manajemen, 14(2), 309-321.

Arini, T. P., Yulia, S., \& Romiko, R. (2018). Hubungan kerjasama tim dengan penerapan budaya keselamatan pasien di ruang rawat inap Rumah Sakit Bhayangkara Palembang Tahun 2018. Masker Medika, 6(2), 406-416.

Arso, S. P., \& Sriatmi, A. (2017). Gambaran Budaya Keselamatan Pasien Di RS Roemani Muhamaddiyah Semarang. Jurnal Kesehatan Masyarakat (e-Journal), 5(1), 118-125.

Hadi, I. (2016). Buku Ajar Manajemen Keselamatan Pasien. Deepublish.

Harsul, W., Syahrul, S., \& Majid, A. (2018). Penerapan Budaya Pelaporan Insiden Keselamatan Pasien di Sebuah RSU Daerah Provinsi Sulawesi Selatan. Panrita AbdiJurnal Pengabdian pada Masyarakat, 2(2), 119-126.

Herawati, Y. T. (2015). Budaya Keselamatan Pasien di Ruang Rawat Inap
Rumah Sakit X Kabupaten Jember. IKESMA, 11(1).

Mandriani, E., Hardisman, H., \& Yetti, H. (2019). Analisis Dimensi Budaya Keselamatan Pasien Oleh Petugas Kesehatan di RSUD dr Rasidin Padang Tahun 2018. Jurnal Kesehatan Andalas, 8(1), 131137.

Siagian, E. (2020). Penerapan Budaya Keselamatan Pasien Oleh Perawat di Rumah Sakit Bandar Lampung. Jurnal Skolastik Keperawatan, 6(1), 62-71.

Simamora, R. H. (2018). Buku ajar keselamatan pasien melalui timbang terima pasien berbasis komunikasi efektif: SBAR. Medan: USUpress.

Simamora, R. H. (2020). Learning of Patient Identification in Patient Safety Programs Through Clinical Preceptor Models. Medico Legal Update, 20(3), 553-556.

Yarnita, Y. (2019). Budaya Keselamatan Pasien pada Perawat di Instalasi Perawatan Intensive RSUD Arifin Achmad Provinsi Riau. Jurnal Keperawatan Priority, 2(2), 109-119. 
Yasmi, Y., \& Thabrany, H. (2018). Faktor-

Faktor yang Berhubungan dengan Budaya Keselamatan Pasien di Rumah Sakit Karya
Bhakti Pratiwi Bogor Tahun 2015. Jurnal Administrasi Rumah Sakit Indonesia, 4(2). 